\title{
Toward Green Battery Cells: Optimization and Characterization of Photo- biphasic Batteries using Liquid Crystals
}

\author{
Amal A. Altalhi* \\ Chemistry department, Faculty of Science, Taif University, Kingdom of Saudi Arabia \\ *Corresponding author
}

\section{A B S T R A C T}

Keywords

Chlorophyll, Algae, Hexagonal phase, Indium tin oxide, Lamellar phase, Open circuit voltage, Short circuit current

Article Info

\section{Accepted:}

18 November 2020

Available Online:

10 December 2020
Photogalvanic cells work by creating high energy products where, the product is excited by a photon; the products, full of energy, release this electrochemically in the form of electricity a concentration change in the two form of redox couple allows the cell to develop a photovoltage. However, Liquid crystals (LCs) are matter in a state which has properties between those of conventional liquids and those of solid crystals. For instance, a liquid crystal may flow like a liquid, but its molecules may be oriented in a crystal-like way, these properties make LCs are promising material to use in photo-biphasic batteries.

\section{Introduction}

Koli studied a photogalvanic cell consisting of Fast Green FCF as photosensitizer, fructose as reductant and $\mathrm{NaOH}$ as alkaline medium has been studied with $1.33 \%$, the observed results are higher and encouraging enough for ultimate aim of development of applicable and affordable photogalvanic cells in future (Koli, 2014). However, Chlorophyll (Vredenberg, 2011) from fresh spinach leaves and algae were studded to produce a novel system and show how cells can be created with very little cost to operate and environmentally friendly. In this work it was prepared self-assembles lyotropic liquid crystals (Andrienko, 2006) in the lamellar $\left(\mathrm{L}_{\alpha}\right)$ phase by using Brij-35 and in the hexagonal $\left(\mathrm{H}_{1}\right)$ phase by using TritonX-100 and use it to produce biphasicphotogalvainc cells 'liquid crystal liquid', study and optimize a series of photogalvanic cells in order to achieve the highest power conversion as well as study the mechanism for power production within the cell. Photogalvanic and photochemistry in general are well studied; however there is still room for huge improvements and investigations within the subject. 


\section{Materials and Methods}

\section{Instrumentation}

Thin films of ITO are used in organic lightemitting diodes, solar cell, antistatic coatings and EMI shieldings. In organic light-emitting diodes, ITO is used as the anode (hole injection layer).

\section{UV-Visible spectrometry}

UV- visible spectrometry was undertaken using a Geneys 10S VIS UV-visible spectrometry system (Thermo Fisher Scientific, USA), with a clear quartz cuvette of path length $1 \mathrm{~cm}$.

\section{Electrochemical measurements}

The electrochemical measurements were recorded using an Autolab PGSTAT30 potentiostat. In all cases, a three electrode system was employed, with nickel wire wound into a spiral serving as the counter electrode, and a silver/silver chloride was utilized as the reference electrode. The working electrode was a $3.0 \mathrm{~mm}$ diameter glassy carbon disc electrode (purchased from BASI,UK).

\section{Reagents}

All reagents were prepared using analytical grade chemicals, and all aqueous solutions were made up using deionized water. Any solvents used were of HPLC grade, and used without further purification, all chemical reagents were purchased from Sigma-Aldrich or Scharlab S.L.

\section{Procedures}

\section{Extraction chlorophyll from spinach leaves}

Plant pigment (a mixture of chlorophylls a and b) (Lehmann, 2011) was obtained using fresh spinach leaves $5 \mathrm{~g}$ were cut into strips and stirred at room temperature in an aqueous acetone solution (4:1 vol./vol. acetone/ water) for ca.120min (Ermakov, 2016), following with filtration, the solvent was removed using a rotary evaporator, and the resulting solid examined via UV/Visible spectroscopy in $5 \mathrm{ml}$ methanol. Percent of chlorophyll $(1.7543 \mu \mathrm{g} / \mathrm{ml}$ total chlorophyll, presented as $1.3904 \mu \mathrm{g} / \mathrm{ml}$ of chlorophyll a and $0.3637 \mu \mathrm{g} / \mathrm{ml}$ of chlorophyll b. Chlorophyll was calculated by using the Arnon equation (Rosen, 2012)

Total Chlorophyll $(\mu \mathrm{g} / \mathrm{ml}): \quad 20.2\left(\mathrm{~A}_{645}\right) \quad+$ 8.02( $\left.\mathrm{A}_{663}\right)$

Chlorophyll a $\quad(\mu \mathrm{g} / \mathrm{ml}): \quad 12.7\left(\mathrm{~A}_{663}\right) \quad-$ 2.69( $\left.\mathrm{A}_{645}\right)$

Chlorophyll $\quad \mathrm{b} \quad(\mu \mathrm{g} / \mathrm{ml}): \quad 22.9\left(\mathrm{~A}_{645}\right) \quad-$ 4.68 $\left(\mathrm{A}_{663}\right)$

Where: $\mathrm{A}_{645}=$ absorbance at a wavelength of $645 \mathrm{~nm}(0.04 \mathrm{~nm})$ and $\mathrm{A}_{663}=$ absorbance at a wavelength of $663 \mathrm{~nm}(0.118 \mathrm{~nm})$. The plant pigment was stored in the dark at $277 \mathrm{~K}$ when not in use.

\section{Extraction chlorophyll from algae}

Approximately $5 \mathrm{~g}$ of algae was weighed out. about $5 \mathrm{ml}$ of acetone was added and grind the algae with a pestle until the acetone turns a bright, deep green. $20 \mathrm{ml}$ of hexane and 20 $\mathrm{ml}$ of distilled water were added to the extract in the tube, then cork it and shake gently. Clearly, there is a cloudy, light green lower water layer and a clear, bright green top hexane layer. Following by filtration then the extract was examined via UV/Visible spectroscopy by using Arnon equation: \% chlorophyll $(1.664 \mu \mathrm{g} / \mathrm{ml}$ total chlorophyll, present as $1.505 \mu \mathrm{g} / \mathrm{ml}$ of chlorophyll a and $0.15866 \mu \mathrm{g} / \mathrm{ml}$ of chlorophyll $\mathrm{b}$ Where: $\mathrm{A}_{645}=$ $0.0326 \mathrm{~nm}$ and $\mathrm{A}_{663}=0.1255 \mathrm{~nm}$ 
Formulation of normal lyotropicliquid crystals

Lyotropic liquid crystals in the lamellar $\left(\mathrm{L}_{\alpha}\right)$ or hexagonal $\left(\mathrm{H}_{1}\right)$ phases (Toamhane, 2009) were prepared in flat-bottomed sample containers, employing Brij 35 or Triton X 100 surfactants, respectively (Gaikwad, 2013). Briefly, surfactant (Brij35 or Triton X 100)/aqueous electrolyte $(\mathrm{KCl})$ mixtures in the mass ratio required by the published phase diagrams were homogenised in the presence of the required amount of redox dopant and photosensitizers chlorophyll, through heating, to approximately $320 \mathrm{~K}$, with stirring, so as to form the micellar isotropic phase, for about one hour. The samples were then allowed to cool, slowly to $294 \pm 2 \mathrm{~K}$.

Table.1 Current-Voltage (i-V) characteristics of the cell $\mathrm{Zn} \mid \mathrm{Zn}^{2+}, \mathrm{CHCl}_{3}$, chlorophyll (spinach)| ITO

\begin{tabular}{|c|c|c|}
\hline $\mathbf{V}$ & $\mathbf{I} \boldsymbol{\mu A}$ & $\mathbf{P} \boldsymbol{\mu W}$ \\
\hline 0 & 24.417 & $\mathbf{0}$ \\
\hline 0.003 & 23.906 & $\mathbf{0 . 0 7 1 7 1 8}$ \\
\hline 0.008 & 22.9544 & $\mathbf{0 . 1 8 3 6 3 5}$ \\
\hline 0.014 & 22.5324 & $\mathbf{0 . 3 1 5 4 5 4}$ \\
\hline 0.02 & 22.0104 & $\mathbf{0 . 4 4 0 2 0 8}$ \\
\hline 0.047 & 21.1114 & $\mathbf{0 . 9 9 2 2 3 6}$ \\
\hline 0.075 & 19.1422 & $\mathbf{1 . 4 3 5 6 6 5}$ \\
\hline 0.103 & 17.1729 & $\mathbf{1 . 7 6 8 8 0 9}$ \\
\hline $\mathbf{0 . 1 9 1}$ & 9.9838 & $\mathbf{1 . 9 0 6 9 0 6}$ \\
\hline 0.245 & 7.1859 & $\mathbf{1 . 7 6 0 5 4 6}$ \\
\hline 0.273 & 5.2166 & $\mathbf{1 . 4 2 4 1 3 2}$ \\
\hline 0.34 & 0 & $\mathbf{0}$ \\
\hline
\end{tabular}

Table.2 Current-Voltage (i-V) characteristics of the cell $\mathrm{Zn} \mid \mathrm{Zn}^{2+}, \mathrm{CHCl}_{3}$, chlorophyll (algae)| ITO

\begin{tabular}{|c|c|c|}
\hline $\mathbf{V}$ & $\mathbf{I} \boldsymbol{\mu A}$ & $\mathbf{P} \boldsymbol{\mu W}$ \\
\hline 0 & 34.08 & $\mathbf{0}$ \\
\hline 0.004 & 33.9792 & $\mathbf{0 . 1 3 5 9 1 7}$ \\
\hline 0.013 & 32.1024 & $\mathbf{0 . 4 1 7 3 3 1}$ \\
\hline 0.022 & 31.4255 & $\mathbf{0 . 6 9 1 3 6 1}$ \\
\hline 0.033 & 30.9983 & $\mathbf{1 . 0 2 2 9 4 4}$ \\
\hline 0.031 & 30.7487 & $\mathbf{0 . 9 5 3 2 1}$ \\
\hline 0.071 & 28.7406 & $\mathbf{2 . 0 4 0 5 8 3}$ \\
\hline 0.114 & 26.5069 & $\mathbf{3 . 0 2 1 7 8 7}$ \\
\hline 0.152 & 23.6491 & $\mathbf{3 . 5 9 4 6 6 3}$ \\
\hline $\mathbf{0 . 2 4}$ & $\mathbf{1 6 . 0 3 1 3}$ & $\mathbf{3 . 8 4 7 5 1 2}$ \\
\hline 0.325 & 8.639 & $\mathbf{2 . 8 0 7 6 7 5}$ \\
\hline 0.446 & 1.5395 & $\mathbf{0 . 6 8 6 6 1 7}$ \\
\hline 0.626 & 0 & $\mathbf{0}$ \\
\hline
\end{tabular}


Table.3 Calculation of max power density, fill factor and power conversion efficiency for each cell

\begin{tabular}{|l|c|c|c|}
\hline \multicolumn{1}{|c|}{ Photogalvanic cells } & $\begin{array}{c}\text { Max power } \\
\text { density }\end{array}$ & Fill factor & $\begin{array}{c}\text { Power conversion } \\
\text { efficiency }\end{array}$ \\
\hline $\begin{array}{l}\mathbf{Z n} / \mathbf{Z n}^{+2}, \mathbf{C H C l}_{3}, \text { Chlorophyll } \\
\text { algae } / \mathbf{I T O}\end{array}$ & $4.932 \mu \mathrm{W} / \mathrm{Cm}^{2}$ & 0.1803 & $\mathbf{4 . 7 7 9 \%}$ \\
\hline $\begin{array}{l}\mathbf{Z n} / \mathbf{Z n}^{+2}, \mathbf{C H C l}_{3}, \text { Chlorophyll } \\
\text { spinach/ ITO }\end{array}$ & $2.444 \mu \mathrm{W} / \mathrm{Cm}^{2}$ & 0.229 & $\mathbf{2 . 3 6 8 \%}$ \\
\hline
\end{tabular}

Fig.1 UV-Vis spectra of $0.1 \mathrm{M}$ chlorophyll from algae, red line in L $\alpha$ phase and green line in $\mathrm{H}_{1}$ phase

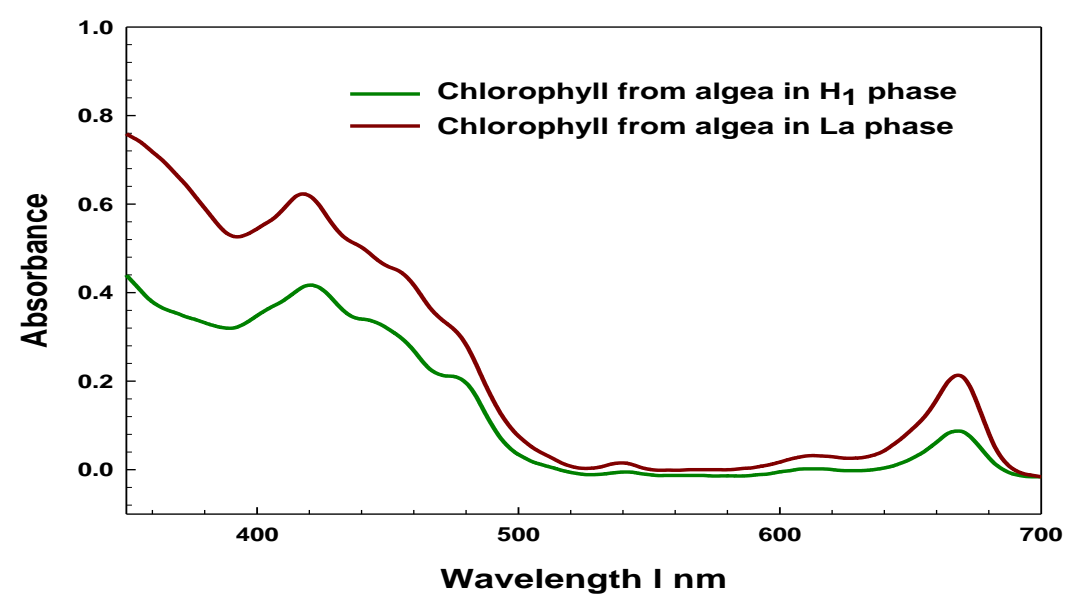

Fig.2 UV-Vis spectra of $0.1 \mathrm{M}$ chlorophyll from spinach, red line in L $\alpha$ phase and green line in $\mathrm{H}_{1}$ phase

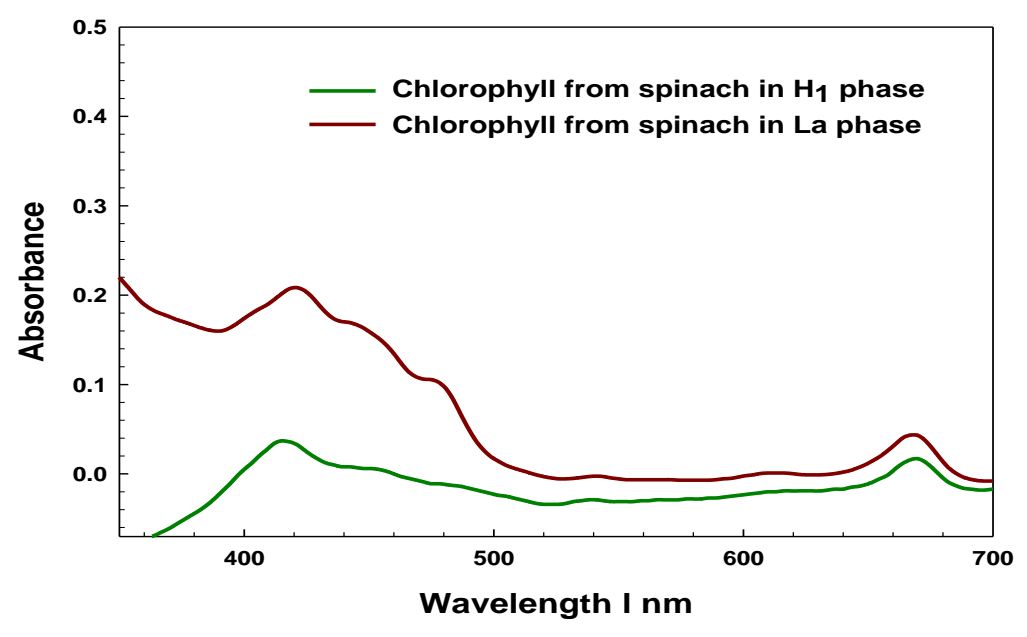


Fig.3 Differential pulse voltammograms of (a) $0.1 \mathrm{M}$ chlorophyll from algae,(b) $0.1 \mathrm{M}$ chlorophyll from spinach in L $\alpha$ phase, initial potential $0.0 \mathrm{~V}$, final potential $0.9 \mathrm{~V}$, with scan rate $0.05 \mathrm{~V} / \mathrm{s}$
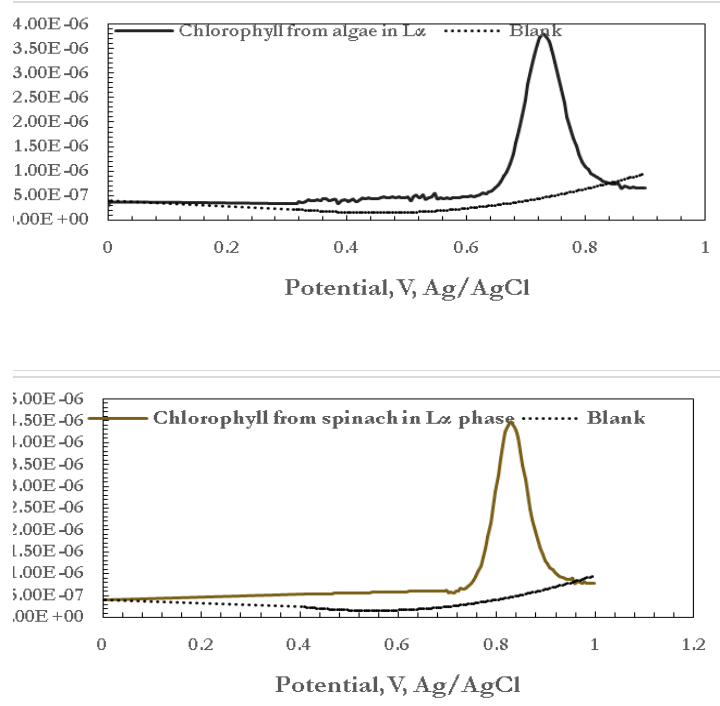

Fig.4 Differential pulse voltammograms of (a) $0.1 \mathrm{M}$ chlorophyll from algae, (b) $0.1 \mathrm{M}$ chlorophyll from spinach in $\mathrm{H}_{1}$ phase, initial potential $0.0 \mathrm{~V}$, final potential $1.1 \mathrm{~V}$, with scan rate $0.05 \mathrm{~V} / \mathrm{s}$
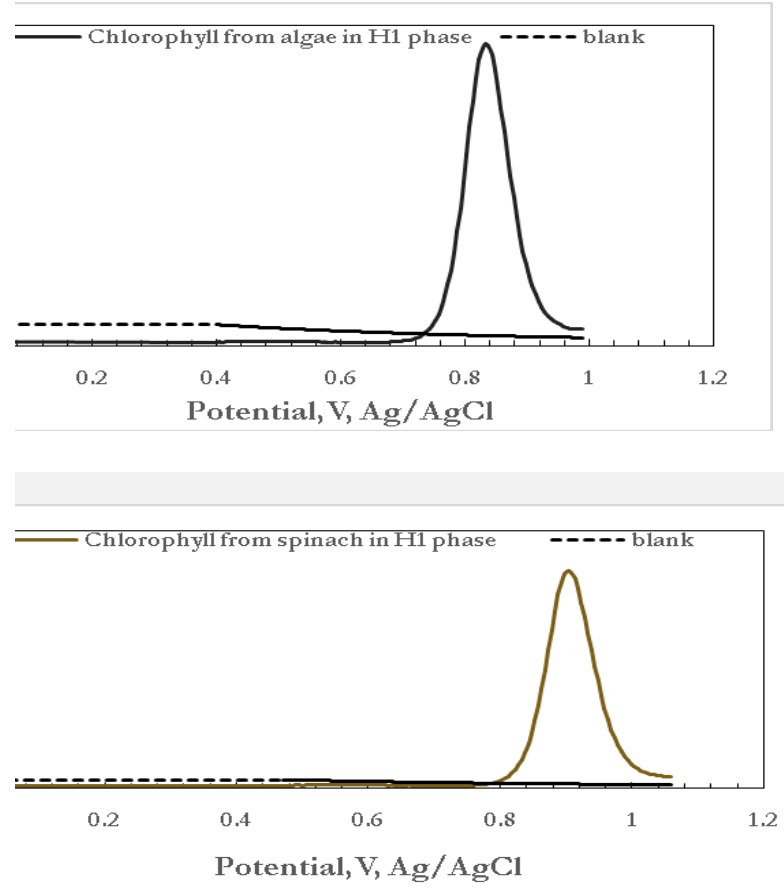
Fig.5 Current-voltage (i-v) curve of the cell (NMP ${ }^{23}$, chlorophyll)

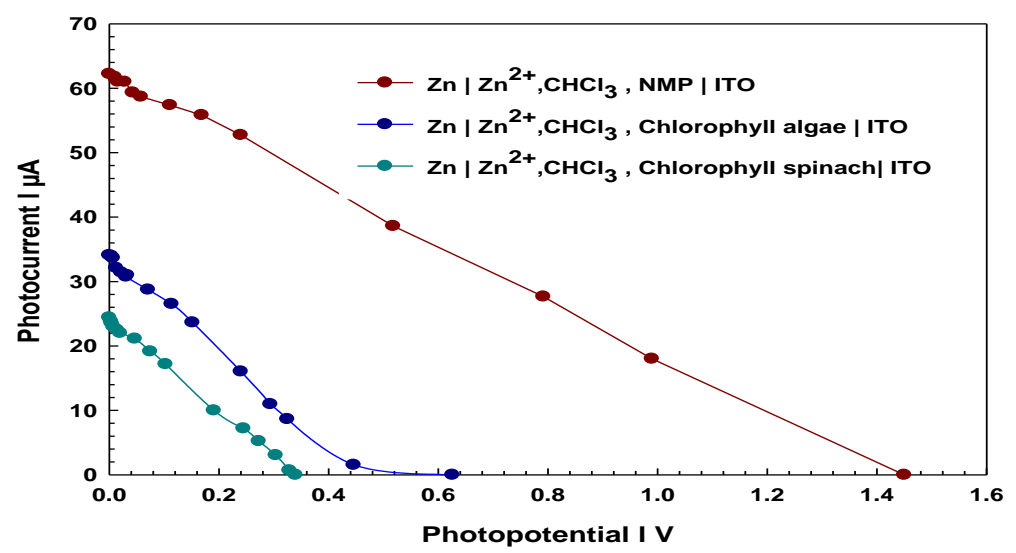

\section{Photo-biphasic batteries}

For this experiment weighted out $3 \mathrm{~g}$ of chlorophyll, $2.5 \mathrm{~g}$ chloroform were add in $5 \mathrm{~g}$ of Brij-35, where $5 \mathrm{~g}$ of $0.1 \mathrm{M}$ potassium chloride was added, this mixture was stirred and heated to $\approx 353 \mathrm{~K}$ for 1 hour (Amos, 2005). An indium tin oxide (ITO) cell was attached with tube then half filled it with then half filled with the chlorophyll liquid crystal and the aqueous $\mathrm{ZnCl}_{2}$ solution was then added on top of it. A long wave UV lamp was then focused on the cell. The cell was irradiated with $350 \mathrm{~nm}$ light. A zinc rod was then placed into the aqueous phase and connected to a voltmeter, ammeter and resistor array. The cell was then tested using a series of fixed resistors as well as a variable resistor. The voltage and current were then recorded after the readings become steady.

\section{UV-Vis spectra of dyes in $L_{\alpha}$ and $H_{1}$ phases}

The experimentally observed absorption for chlorophyll from algae observed absorption maxima is $\pi$ to $\pi^{*}$ peak at $418 \mathrm{~nm}(2.97 \mathrm{eV})$ in $\mathrm{L}_{\alpha} 0.6230$ and in $\mathrm{H}_{1}$ phase the absorbance is 0.4140 and $n$ to $\pi^{*}$ peak at $667 \mathrm{~nm}(1.86 \mathrm{eV})$ in $\mathrm{L} \alpha 0.2120$ and in $\mathrm{H}_{1}$ phase the absorbance is 0.0870 Figure 1. Also we have spectrum for chlorophyll from spinach leave show less absorption in $\pi$ to $\pi^{*}$ peak at $418 \mathrm{~nm}$ (2.97 $\mathrm{eV}$ ) in $\mathrm{L} \alpha \quad 0.2070$ and in $\mathrm{H}_{1}$ phase the absorbance is 0.0360 and $n$ to $\pi^{*}$ peak at 667 $\mathrm{nm}(1.86 \mathrm{eV})$ in $\mathrm{L} \alpha 0.0435$ and in $\mathrm{H}_{1}$ phase the absorbance is 0.0160 Figure 2. So it can be seen that the L $\alpha$ phase observed higher absorbance than $\mathrm{H}_{1}$. Note, the calculation of the energy band from the wavelength was used this formula (Patzelt, 1974): Energy (E) $=\frac{h \times c}{\lambda}$, where, Energy $(\mathrm{E})=$ band gap, planks constant $(\mathrm{h})=6.626 \times 10^{\wedge 34}$ Joules $\mathrm{sec}$, velocity of light $(C)=2.99 \times 10^{\wedge}{ }^{8}$ meter $/ \mathrm{sec}$ and wavelength $(\lambda)=$ absorption peak value. Also $1 \mathrm{eV}=1.6 \times 10^{\wedge-19}$ Joules (conversion factor) (Mahmoud, 2015).

\section{Determination of dyes by differential pulse voltammetry (DPV)}

The DPV (Liang, 2017) exhibited anodic peak at about $0.7179 \mathrm{~V}$ and $0.8431 \mathrm{~V}$ corresponding to the oxidation of chlorophyll from algae and chlorophyll from spinach in L $\alpha$ phase respectively Figure 3. Also exhibited anodic peak at about $0.8382 \mathrm{~V}$ and $0.9132 \mathrm{~V}$ corresponding to the oxidation of chlorophyll from algae and chlorophyll from spinach in $\mathrm{H}_{1}$ phase respectively Figure 4 . Surfactant changes the potential peak for each dye and therefore the charging current. The peak potential at L $\alpha$ phase has lower than at 
$\mathrm{H}_{1}$ phase. The height of the current wave of each dyes in L $\alpha$ phase was found to be higher than in $\mathrm{H} 1$ phase. Therefore, the L $\alpha$ phase was chosen for use in design of photogalvanic cell.

The effect of light harvesting agent on PC: $\mathrm{Zn} \mid \mathrm{Zn}^{2+}, \mathrm{CHCl}_{3}$, Chlorophyll | ITO

The active, light harvesting, agent of the cell was then changed to see if further deviations on the system could be produced. The use of Chlorophyll, a large and conjugated species, was hoped to invoke much larger power efficiencies and absorb more of the UV light thus driving power production. As you can see from Figure 5 chlorophyll from spinach and algae none of the cells produced a large enough max power or a significantly large power conversation to warrant further study, the reason of lower conversion of chlorophyll (spinach) is the molecular weight of chlorophyll is big and it was concentrated more than chlorophyll (algae)so the excitation and the movement of electron and photon is low and we can see that clearly from UV-vis spectroscopy despite the energy band is lower than NMP but it can be noticed the peaks of chlorophyll accrue in the vis region not in the UV wavelength. Table 1 show current-voltage (i-V) characteristics of the cell (chlorophyll spinach) and Table 2 show Current-Voltage (i-V) characteristics of the cell (chlorophyll algae) (Table 3 ).

In conclusion the poor efficiency of chlorophyll still requires some explanation. This may be due to the size of the molecule and so the ability to move around the system that limits its efficiency (Yano, 2017). The back reaction may also prove to be prolific. It may be advantages to try this cell with a surfactant molecule present and above the critical micelle concentration (CMC). This would reduce the rate of the back reaction if it is under diffusion control. Further cell containing different metal ions were discarded due to poor efficacy. Although these devise may prove efficient after further work the time constraints of this project impeded further study.

\section{References}

Amos, B.2005. Birefringence for facetors, the Journal of the UK Facet Cutter's Guild. January-March. Edition, 2005.

Andrienko, D.2006. Introduction to liquid crystals. IMPRS school, Bad Marienberg.

Ermakov, S., Beletskii, A., Eismont, O. and Nikolaev, V. 2016. Brief Review of Liquid Crystals, in Liquid Crystals in Biotribology, Springer. p. 37-56.

Gaikwad, P.P. and M.T. Desai.2013. Liquid crystalline phase and its Pharma application. International journal of Pharma Research and Review, 2(12): p. 40-52.

Koli, P.2014.Solar energy conversion and storage: fast green FCF-fructose photogalvanic cell, Applied Energy, 118, 231-237.

Lehmann, O. 2001. Design of liquid crystalline materials.

Liang, Y., and D, Urano. 2017. A nondestructive method to estimate the chlorophyll content of Arabidopsis seedlings. Plant methods, 13(1): p. 26.

Mahmoud, S.A. and B.S. Mohamed.2015. Study on the Performance of Photogalvanic Cell for Solar Energy Conversion and Storage. Int. J. Electrochem. Sci. 10: p. 3340-3353.

Patzelt, W.J. 1974. Polarized light microscopy. Wetzlar, Germany: Ernst Leitz.

Rosen, M.J. and J.T. Kunjappu.2012. Surfactants and interfacial phenomena: John Wiley \& Sons.

Tamhane, K. 2009. Formation of lyotropic liquid crystals through the self-assembly 
of bile acid building blocks.

Vredenberg, W. 2011, Kinetic analyses and mathematical modeling of primary photochemical and photoelectronchemical processes in plant photosystems. Biosystems, 103(2), 138151.
Yano, J. and Kitani, A. 2017. Photo-assisted flavin mediated electro-oxidation of $\mathrm{NADH}$ model compound using photogalvanic cell. Journal of Electroanalytical Chemistry, 799: p. 431-435.

\section{How to cite this article:}

Amal A. Altalhi. 2020. Toward Green Battery Cells: Optimization and Characterization of Photo-biphasic Batteries using Liquid Crystals. Int.J.Curr.Microbiol.App.Sci. 9(12): 29332940. doi: https://doi.org/10.20546/ijcmas.2020.912.348 